\title{
Small Scale Mining in Belinyu District
}

\author{
F.R.Harahap \\ Program Studi Sosiologi, Fakultas Ilmu Sosial dan Ilmu Politik, \\ Universitas Bangka Belitung Indonesia \\ dha3n@yahoo.com
}

\begin{abstract}
Small scale mining has given positive contribution to Bangka Belitung Province and its people, particularly in Belinyu Subdistrict. As the consequence, local government issued certain policy for illegal Small scale mining. It is aimed to stop all activities of Small scale mining. However, the effort made by government and police do not reduce significantly tin mining activities. Moreover, the illegal tin mining is still running and even increased up until now. The aim of this research is to describe the form of resistance strategies of Small scale miners in facing local government and police officers inspections in Belinyu Subdistrict, Bangka District, Bangka Belitung Province. Qualitative research method was used to answer research questions particularly for gathering and analyzing data. Research instrument used in this study was the researcher herself aided by recording device and fieldnote. Informants of the research were selected by using purposive sampling. Data gathering technique used was in depth-interview and documentation study. The result of this stuides are Small scale miner seen as skillful and knowledgeable subject in choosing resistance strategy. Meanwhile, macro perspective states how Small scale miners make use the structure e.i. resources such as network and social organization in their social system. The research finding shows that tin miners choose illegal tin mining with several strategies; first, by using organization, second, by monitoring local government and police officer inspection, third by avoiding the inspection and the last by concentrating the tin mining activities in one mining region
\end{abstract}

Keywords: Small Scale Minning, Social Movement, Resistance Strategy

\section{INTRODUCTION}

In Indonesia, the area includes Tin reserves, Kundur, Karimun island of Singkep, and partly in the Mainland of Sumatra (Bangkinang) North continues South towards the island of Bangka, Belitung and Kari Mata Islands up to the area west of Borneo. Tin mining in Bangka has started in 1711, in Singkep in 1812, and in Belitung in 1852. (3)

The resource wealth of Tin mines can be seen from Indonesia ranked Indonesia as the world's largest Tin producer. In 2006, according to data of the International Tin Research Institute (ITR), the two companies lead in

Indonesia included in ten of the world's largest Tin producer. PT Timah Tbk was ranked second with production of 44.689 tones and PT Koba Tin is ranked seventh with production of 20.930 tons. (13, p45)

While the first stage was occupied by the Yunan Tin, a Tin company in China with production amounted to 52.399 tones. Before the autonomy areas, resource management Tin mines in Indonesia is carried out based on the implementation of law No. 11 of 1967 concerning Basic provisions of mining. There are two companies were given permission by the Central Government, namely PT Timah and PT Koba Tin. The only two companies that can have access to the tin mining in Bangka Belitung Islands Province.

The changes that occur as a result of the publication of the Minister's decision Industrial and trade no. 443/2002 on changes to the Annex of decision Industry and the Minister of Trade No. 558/MPP/KEP/12/1998 on general provisions in the field of exports, Trade Minister Regulation No. 07/M-DAG/PERI4/2005 about the changes to the decision of the Minister of Industry and Trade No. 558/MPP/KEP/12/1998 on general provisions in the field of exports, last modified by decision of the Minister of Industry and Trade no. $385 / \mathrm{MPP} / \mathrm{KEP} / 6 / 2004$, the provincial government is understood as the freedom to manage and set the tin mining in Bangka Belitung.

The Central Government policy changes the Government responded by giving the Bangka district business license smelters of Tin (tin ore smelting company became the metal lead), Published local regulations Bangka District No. 6 of 2001 about the management of the Public Mining, applicable local Bangka District No. 20 of 2001 About the determination and arrangement of Strategic Goods Trade, as well as applicable local Bangka District No. 21 of 2001 concerning the taxation of Public Mining and minerals, as a follow-up to the implementation of decisions of the Minister of Industrial and trade of the previous export. (13, p99-100)

The growth was also accompanied by the expansion of the smelter mines run by local people. Rampant mining folk, in addition to associated with Tin prices are quite high, also because of the existence of many smelters in need of raw materials is quite a lot. This is because almost all of the existing smelters in Bangka do not have its own mine site so they are subject to the miners of the people. $(18, \mathrm{p} 119)$

In addition to the effected by regulation as described previously, the development of the tin mining also stimulated by two other factors. First, a decision at the beginning PT. Timah-1990s to download subcontracting tin mining project portion of land to local businessmen due to the crisis lead the world in 1985 . On the pattern of subcontracting is the first time the term people's Tin mining was introduced, namely the mining cooperation forms with the ability to move the soil less than $30 \mathrm{~m}^{3} / \mathrm{h}$, the lowest capacity in modern mining system. Second, the fall of the major agricultural commodity prices Bangka i.e. Pepper at the end of the 1990's caused decrease the income of local communities. Third, at the same time, the separation of Bangka Belitung off South Sumatra Province as a result of implementing policies of 
the autonomous region led to the weak system of Government on the island of Bangka Belitung. (18, p8)

The rise of tin mining people positively impact on the economy of Bangka Belitung Islands province and residents of the community. Tin mining people give a huge financial benefits. Thousands of homes on the edge of the road that was once made of wood or bamboo have now been on the renovation the owners become like home in urban with a complete electronic devices and vehicles.

However, the negative impact arising out of tin mining people anyway. (14) Tin mining people cause pollution of the sea. Fisherman's marine pollution losing livelihood because they can no longer catch fish in the sea that has been contaminated by tailings. In addition to it, at the village Air Anyut, Bangka Regency, its own pollution and damage has occurred the river water. Local drinking water companycomplained their water supplies from polluted. Water pollution also occurs in the rice paddies of rice production decreased thus affecting in Bangka Regency. Palm oil plantations have complained of the same things as their plantation riddled with small holes the former tin mining minerals. The forest in the Bangka Belitung along with reduced because after dwindling pepper plantation was replaced with tin mining. $(4, \mathrm{p} 17)$

Tin mining developments that negatively affect people's as mentioned earlier made the Government reacts by issuing policies regulate people's Tin mining which does not have permission. As confirmed by the Chief of Police Region of Bangka Belitung at that time, the Commissioner of police Imam Sudjarwo, that Tin minesare secured Tin mines that are unlicensed and prohibited strikes in place.

Bangka district itself is an area that was first issued local regulations the response to the Minister's decision No. $443 / 2002$ concerning the export of Tin as a strategic commodity. The promulgation of the regulation of this area as an attempt to raise revenue (PAD) areas of the original. Bangka Regency Government then makes the Regulation of this area as a juridical basis for conducting surveillance and management of minerals of Tin with regulate. However, the efforts made by the Government and police did not reduce people's Tin mining significantly.

\section{THE PURPOSE OF THE RESEARCH}

Bangka Regency Government banned lead mining activity of decisive people who do not have permits mining by reason of its development is considered to have been unsettling, especially has resulted in environmental damage was very severe. In addition, as a consequence of mining business license he had not, then citizens did mine without any obligation to perform reclamation andpay royalties, and little regard for the safety and occupational health. Finally the Government banning the activities of tin mining against curbing the people who do not have permissions as an attempt to stop the tin mining activities of the people. However, in reality the activity action carried out by the Government with the juridical basis i.e. local regulations does not show the results as expected, even up to this moment the people's lead mining without permission of the mining business is still running and growing.

Developing and persistence of small scale mining in a situation of Government interdiction is related to strategies used by the Tin miners of the people, the purpose of this research was: describe the forms of Tin miners resistance people's strategy in curbing the activities of the strategy by the local government and police in district Belinyu, Bangka Regency, Bangka Belitung Islands province.

\section{A Study Of The Literature}

\section{A. The Artisanal Tin Mining}

Artisanal mining are mines that are managed by the general public, and those who perform mining activities commonly known as artisanal miners. Artisanal miners mining generally in locations that have a mineral content but not managed by large companies. Perceptions of tin mining as mining folk (non PT. Timah Tbk and PT. Koba Tin) originally done in a simple, but now most have been operating with systems and tools resembling or nearly resembling systems and tools that are used by PT. Timah Tbk and PT. Koba Tin. There are a licensed Mining Authority but mostly without permission Authorization for Quarry, some operating without permission in Mining Authorization PT. Timah Tbk and PT. Koba Tin. Definition and characteristics of the people is actually a tin mining classification used by PT. Timah Tbk for a mining operation to mine the material removal capability under $30 \mathrm{~m}^{3} / \mathrm{jam}$. However, this notion is now shifted into tin sand mining activities conducted by the society in general does not have a mining business license from the government. As a consequence of this condition is not licensed, then the mining community without any obligation to reclaiming and pay royalties. Tin mining folk character reflects a mining activity that is less and less attention to environmental health and safety aspects. (18, p8-10)

\section{B. The Roots of The Conflicts with the Government's Mining}

Conflicts in mining area is essentially an asymmetric conflicts where the parties in conflict are not on the same position of power. Mining companies that have a legal aspect in the form of Mining Authority; legally entitled to make the exploitation of natural resources. Instead, locals or newcomers who made their living as miners (usually without the legal aspects) also feel entitled to get their livelihood from these natural resources.

This situation is exacerbated by lack of local government roles in bridging the differences in perceptions and behavior of those involved in the conflict. When viewed in a macro, in the area of mining conflicts caused by differences of interest between Central Government and local governments. The role of Central Government through its policies which directly regulate the company's presence in the area, often do not pay attention to the interests of the region. (16, p4-5)

In General, the conflict that developed in the area of mining in Indonesia rise to the surface due to the nature that is typical of the mining area. The mining area is usually located in a relatively remote area and have not been so developed including the community around it. Meanwhile, the mining activities which do require advanced technology and facilities. As a result, appeared bottomless gap between the mining company and the local community that gave rise to conflict between the company and the community. $(15, \mathrm{p} 5)$ 
Meanwhile, the conflict in the area of tin mining in Bangka Belitung Islands province was born as driven by the policy changes in Commerce national lead coincides with the fall of the price of pepper mainstay source of livelihood of the local population. This condition occurs because of heightened euphoria of reform which makes people more willing to express their aspirations, while on the other side of the security forces hesitate to act tough because often cornered by the issue of human rights violations. $(18, \mathrm{p} 17)$

If seen from the actor's conflicted between the miners and the company, the conflict in the area of tin mining in Bangka Belitung indicated that the actors involved have not experienced a loss, even mutual benefit. The company allows people to mine the miners in the Mining Authority his so that companies can buy the Tin miners of folk production to meet sales quotas. However its development, the conflict finally comes as miners' people sold some results of his rope to the other party, namely the smelters or smuggle it abroad because of the price difference significant. (18, p15)

\section{Strategies of Resistance}

In a general sense, the strategy is a way to get a win or achieve goals and strategy is essentially the art and science of using and developing power of ideological, political, economic, social, cultural and defence security, to achieve the goals that have been set previously. Therefore, the strategy can be used as art and science as well as the way in the form of actions against to get a victory, so to win a resistance, a planned strategy and required careful consideration by using the forces as well as existing resources.

Roger M. Keesing in concept (7) of culture examines knowledge and strategies associated with the environment and ways of gaining life. Knowledge and strategies (such as creating a tool to form working groups) is part of the realm of the ideational he termed culture. The ideational patterns for living, the patterns of meaning and knowledge systems and the trust which is owned jointly by the subsystem is very important regarding "a way of life in the environment". How to live in the environment by experts cultural adaptation is named as "the socio cultural systemenvironment" that is adaptive and maladaptive and depends on the process of natural selection. (7)

Related to the strategies of resistance, then Scott (11) defines the resistance as any act committed by a subordinate Group devoted to reducing the or reject the claim (such as rents or taxes) made by a group of superordinate against them He split the opposition into two parts, namely: public resistance or open (public transcript) and resistance is hidden or closed (hidden transcript). Both of those categories, differentiated articulation of resistance; forms, social characteristic and cultural areas. Resistance has been characterized by the presence of open interaction between the subordinate classes with classes superordinate. While resistance to surreptitious has been characterized by the existence of reclusive, indirect interaction between the subordinate classes with classes superordinate. (11, p35-36)

If it refers to a thought-provoking Dahrendorf, resistance is a class struggle (class struggle) conducted by the class that does not hold the authority as a resistance against the authorities in organizational systems between groups that have control over the means of production or management positions with authorities and labor is not holding the authority. (6, p46-47)

According to Marx, while what is championed by the individuals and social groups as a form of resistance based on the social nature of man who is always fighting for the basic necessities of life. Marx believed that the basic needs as a foundation structure refers to the materialistic needs by creating tools and production systems so that the material needs can be met. However, despite the fulfillment of basic human needs can be done by creating tools and production systems in the process of struggle, the fulfillment of the basic needs of social groups will always have conflict with other social groups due to the difference of power that is specified by the power of capital owned in order to create the tools and the production system. (Susan, Novri 2009, p. 36)

According to the strategy, Afrizal (1) resistance refers to the ways or methods used as joint action or collective action. Joint actions (collectively) are the actions undertaken by the community's understanding of the situation and is a creative response to the actions of companies and Government agencies, not just a response the response without any reflection on the actions of companies and Government agencies. (1, p42) Social movements are one of the main forms of collective behavior which is a collective ways to support or reject the changes.

The study of Sociology emphasizes relative deprivation, i.e., situations where the expectations of the people or groups do not correspond to the reality of that happening, also emphasized the role of the mobilization of resources (resources mobilization who gave me) that an effective organization, tactics, and the leaders of the movement.

\section{Strategic Forms of Resistance}

According to McAdam, McCharty and Zald Moodie (8), strategies of resistance also residents or local communities such as Tin miners were done by the people, is part of a discussion of the theory of the structure of the mobilization in the social movement studies politics. McAdam, McCharty and Zald (8) also mentioned that good organization form of informal and formal as well; available for mobilizing resistance to the term structure. This theory is used to analize the emergence and development of a social movement or revolution. McCharty (8) revealed that the structure of the mobilization are a number of ways the Group social movements are fused in a collective action, including movement tactics and form of organization of social movements. The structure of the mobilization include a series of social positions in everyday life within the structure of mobilization, the aim is to find a micro locations in society to be mobilized. Social sites are among other things is one's family units, friendship networks, associations, volunteers units work, and elements of the State. (7, p7)

According to Heyzer, there are three patterns of social networks developed by the Homesteader and labor factories, namely (1) a social network based on the system of kinship and family; This network was created deliberately to overcome poverty and sustaining life, (2) social network adjacency or friendship; This network was formed to meet the needs at the level of the groupbecause of the similarity of 
religion, ethnicity, and others, (3) social network witha vertical relationship patterns; the pattern of this relationship is usually formed based on patron- client relationships for farmers and labor for foreman. These social networks are formed as a manifestation of unsafe conditions andvulnerable to the crisis so that the much needed social network support. (2, p118)

In the case of peasant social movements by Wahyudi, a support network of people who wield political power is in dispensable. Socio- political power holders into thenetwork of social movements, so that they can create political opportunities. with this endorsement makes social movements actors and participants can move freely without any fear of legal or political. If the thought of Marx, refers to the Organization's strategy will be effective if the struggle is done through the revolution, and will succeed if the following two factors are met i.e., first; realize himself or his group as people who are oppressed by the second objective, class consciousness; classify themselves in a container such as labor organizations, because if it is done on an individual basis, it will be difficult to fight for his claim. $(9, \mathrm{p} 77)$

Organizational conditions should be expanded and organized, the more the number, the more concentrated so that they are more powerful, struggle into a political movement and becomes a struggle with a longeffort. While according to Dahrendorf, the resistance as a class struggle is only possibleif the group does not hold the authority to have an awareness of the interests against the occurrence of a change and formed interest groups. Requirements that are owned by the class struggle through awareness classes and interest groups are: the technical condition is characterized by the presence of leadersand ideologies or beliefs, namely freedom of political conditions to form groups or organizations and action groups, social conditions, namely the level of communication between all members of the group, in addition to the consistency of membership in a class or group in a class or group, and the existence of political affiliations.

\section{RESEARCH METHODS}

Research methods used are qualitative research methods with types of descriptive research. Research instrument used is the researcher himself, aided by the recording device, and a note field. Selected research informants by using purposive sampling techniques and data collection techniques used are in-depth interviews with miners lead 7 persons interviewed people and study documentation with secondary data be gathered newspaper, government agencies report, tin mining activity related articles, correspondence, documents, maps, mining areas and other documents. This research was carried out during the six months since February until July 2012, with research location in district Belinyu, Bangka Regency, Bangka Belitung Islands province, where the Belinyu is one of the districts most contributed in producing metal Tin and tin ore.

\section{RESULTS AND DISCUSSION}

\section{A. The causes of people's Resistance of Tin Miners}

Mining activities lead into solution work to meet the needs of citizens living, because employment options in other areas considered not giving satisfactory results because the tin mining more promising instant results with capital and skills set. Residents initially worked as farmers pepper and rubber, fishermen, merchants, switch into the Tin miners because of the tantalizing results. People's licences in Act No. 4 of 20092009 about mineral and coal mining are termed people's Mining Permit. After regional autonomy, natural resources management, such as licensing of lead were under the authority of the Government of Bangka district according to Perda No. 6 of 2001on the management of General mining. Bangka Regency, for Governments that become the basis of people's Tin miners are unlicensed mining, in addition to the emergence ofimpacts that ecologically the more severe and alarming. Therefore, the Government was finally able to stop all forms of tin mining activities of the people who do not have the people's licences. Meanwhile, according to the Tin miners of the people, the Government is not aspirational and accommodating to their interests, so that this condition was used as the basis for conducting resistance.As for the matter of resistance carried out by miners lead the people against government policies especially regional government regulations on setting up common rule regarding mining licences. Insubstance, the people's Licences considered trouble some because they have limitations that are too narrow. For example, mining activities conducted byindividuals can only use simple non mechanical or equipment with 2 (two) machines consisting of a maximum of 20 PK (based on Perda No. 6 of 2001, article 24). If using a machine with the power miners was only able to move a little amount of land. While the current lead is the more difficult it gets for having to dig into the soil to a depth of 12 meters. According to the tool in accordance with the miners the legislation is unlikely to be used. Another option which is owned by the citizens of the community to performmining activities is to take care of Licences exploration and mining business license exploitation. However, it is envisaged that the terms and procedures that must be met are quite complicated. The problems are difficult to be faced by citizens when taking care of permits is had to deal with the bureaucratic and governmental agencies in related procedures, which already is known for its culture of corruption. Residents must eventually provide some funds or money to be used to take care of some requirements such as letters of recommendation from the local government as the head of the village and also head of relevant agencies. Imagine how many funds should be provided by the miners. Not to mention the question of document of environmental impact assessment or list of experts as well as a must- have. Because of that, miners did not take care of licensing.

\section{B. The Tin Miners Resistance people's Strategy}

Miners lead the people chose a number of ways or methods for conducting resistance against the Government and its policies by means of careful and well-planned. Ways or methods is carried out using powers or resources that it owns. Related thinking Giddens (5), how miners decided the choices about the right strategy is inseparable from the ability possessed 
by the tin miners of the resistance against the Government. The strategies chosen by the people of tin miners struggle to realize the goal consists of using the organization, monitor the activities of law enforcement officials, avoiding demolition activities, and concentrate mining activities in the region. First, miners use the organization by becoming a member or trust of the organization at the sub-district and district levels. Tin miners active people to pay dues and contribute to the organization, following the activities such as meetings, meetings held by the organization. Organization makes "dark pact" with the smelter where miners would only sell the mine to the designated collector. Secondly, miners monitor enforcement activities undertaken by the authorities. The miners have speakers in the bureaucracy implementing monitoring. Miners have to know which of these elements can be used as a resource for information. The relationship between the miners with sources previously been established and built a network of friends that is based, therefore sometimes there is no reward given to the informant. The miners active contact elements of the police and government departments to find out plans demolition activities. This monitoring effort only managed to anticipate enforcement activities that have been scheduled on a regular basis or will be done. As for the forms or types of activities that are not scheduled demolition or demolition activities undertaken sudden or inspection, needed another strategy more effective. Third, avoid enforcement officers who perform enforcement activities to avoid unscheduled or impromptu conducted previously unnoticed. Evasive action performed by the miner is by way of utilizing the existing circumstances around miners. The circumstances are, among others; ground conditions in the mining area that is open and spacious, also the condition of the soil surface with holes as a result of excavation of mining activities, and social situation of the people that are around the area who still know each other mining systems are still strong social ties. In addition, miners also perform other actions that are deemed effective escape when officers will conduct enforcement activities was nearing the location of mining activities. This avoidance strategy has drawbacks. The drawback is that the mining area is open and spacious, and the condition of the soil surface with holes can not always be used to help miners escape from the mine site when the officers approached the mine site. Mining area is also wide open as well and still could be an opportunity for officers who perform an audit to see the miners who run and mengerjarnya though not easy. Hollow underfoot conditions it can be a scourge for miners, because of the fragile soil structure in the surface soil can cause landslides that buried miners are hiding and could actually cause death to miners. By karen it needed another strategy that is more effective as it will be described below. Fourth, the concentration of mining activities in the mining area to fight the government's policy is not related to its mining business license so that they are disciplined by the authorities and with the efforts of many miners also avoid illegal levies in the form of a donation request. Done in ways that are coordinating and mobilizing miners to join a mining region, then the people tin miners also appoint a designated manager is so that miners can manage and protect mining mining activities performed by unlicensed miners. The role of the manager to manage mining activities that regulate the distribution of mining sites scramble to avoid conflicts among fellow miners mine site, set up costs such as the cost of mining management that aside from the mining results are submitted to the head of the village, the management fee as compensation for managers, the cost to the security, the cost for donation requests from certain parties (thugs, remaj mosques, youth clubs or local youth, and so on). While the protective role that is performed by the manager arranged for miners activity is not disturbed by the consequences that may result from mining activities without permission they are doing. Consequences include demolition activities are affected by agents and illegal fees that are often experienced by miners. Effectiveness of actions concentrating miners mining activities in the mining area can be seen from the extent to which miners successfully against government policies, especially related to the control of mining activities without permission. By concentrating the mining activities in the area of mining, the miners more coordinated and stronger to perform collective actions.

\section{CONCLUSION}

Enforcement efforts undertaken by the local government to stop mining activities lead people who do not have a mining business license by way of enforcement activities are scheduled, as well as controlling the activities carried out by the surprise inspection (inspection). Enforcement activities conducted by the Civil Service Police Unit in coordination with relevant agencies such as the Police of Bangka District, Ranger, Army Police Water, and the Department of Mines and Energy Bangka Regency. Enforcement efforts by the government circumvented by miners in a way that is first; using organization to fight against the local government policy, second; monitoring activities conducted by law enforcement officials to develop a strategy that miners face recana enforcement officials, third; evade law enforcement officers who carry out activities that miners are not caught when officers carry out enforcement activities, and the fourth; mining activities concentrate in the tin mining area so miners can be coordinated and mobilized together to oppose government policies and overcome illegal levies. Actions of the people that deal with tin miners enforcement activities carried out by officers against government policies deemed to be aspirational and accommodating to the interests of miners. The policy in question is the rule both artisanal mining activities listed in Law and Local Regulations have narrow bounds with the terms and procedures convoluted make miners became reluctant to take care of the mining permit does. Therefore, people tin miners maintained resistance in ways or strategies as outlined above so that they can fight for the chance to manage the resources available tin mine so that it can continue to carry out mining activities.

\section{REFERENCES}

[1] Afrizal. Sosiologi Konflik Agraria: Protes-protes Agraria Dalam Masyarakat Indonesia Kontemporer. Padang: Andalas University Press; 2006.

[2] Afrizal, editor. Pembangunan Dan Konflik: Hasil-hasil Penelitian Para Dosen Ilmu-ilmu Sosial Universitas Andalas. 
Padang: Andalas University Press; 2010.

[3] Batubara Marwan. Menyelamatkan Kehancuran Pertambangan Timah Bangka Belitung (1). [Internet]. [Placed unknown]. [cited 23 January 2010]. Available from: [http://www.eramuslim.com/berita/ laporankhusus/menyelamatkan- kehancuran-pertambangan-timahbangka-belitung- 1.htm\#.U7IAE5SSzgs].

[4] Erman Erwiza. Rethinking Legal and Illegal Economy: A Case Study of Tin Mining in Bangka Island. J Southeast Asia; History and Culture. 2008; 37: 91-111.

[5] Giddens Anthony. 1984, The Constitution of Society; Outline of The Theory of Structuration, translated by Adi Loka Sujono, 2004, The Constitution of Society; Teori Strukturasi Untuk Analisis Sosial. Malang: Pedati; 1984.

[6] Haryanto Sindung. Spektrum Teori Sosial: Dari Klasik Hingga Postmodern. Jogjakarta: Az-Zura Media; 2012.

[7] Keesing Roger M. 1974, Theories of Culture: Annual Review of Anthropology, translated by Amri Marzali, Teori-teori tentang Budaya. [Internet]. [Place unknown]; 1974 [cited 2 January 2013]. Available from: http://www.scribd.com.

[8] McAdam Doug, et al. Comparative Perspective on Social Movements: Political Opportunities, Mobilizing Structure, and Cultural Framing. London: Cambridge University; 1999.

[9] Raho SVD Bernard. Teori Sosiologi Modern. Jakarta: Prestasi Pustaka; 2007.

[10] Situmorang Abdul Wahid. Gerakan Sosial: Studi Kasus Beberapa Perlawanan. Yogyakarta: Pustaka Pelajar; 2007.

[11] Scott James. Senjatanya Orang-orang yang Kalah: Bentukbentuk Perlawanan Sehari-hari Kaum Tani. Jakarta: Yayasan Obor; 2000.

[12] Susan Novri. Pengantar Sosiologi Konflik Dan Isu-isu Konflik Kontemporer. Jakarta: Kencana Prenada Media Group; 2010.

[13] Susilo Joko, Siti Maimunah. Tiga Abad Melayani Dunia: Potret Tambang Timah Bangka Belitung. Jakarta: Jaringan Advokasi Tambang; 2009.

[14] Yunianto Bambang. 2009, Kajian Problema Pertambangan Timah Di Provinsi Kepulauan Bangka Belitung Sebagai Masukan Kebijakan Pertimahan Nasional. J Teknologi Mineral dan Batubara. 2009; Juli 5(3):97 - 113.

[15] Zulkarnanin Iskandar, Tri Nuke Pudjiastuti. Panduan Pemberdayaan Masyarakat Di Kawasan Pertambangan. Jakarta: LIPI; 2006.

[16] Zulkarnanin Iskandar, Tri Nuke P, Umi Karomah. Potensi Konflik Di Daerah Pertambangan: Kasus Pongkor dan Cikotok. Jakarta: LIPI; 2003.

[17] Zulkarnanin Iskandar, Tri Nuke P, Anas, et al. Konflik Di Daerah Pertambangan Menuju Penyusunan Konsep Solusi Awal Dengan Kasus pada Pertambangan Emas dan Batubara. Jakarta: LIPI; 2004.

[18] Zulkarnanin Iskandar, Erwiza Erman, Tri, Nuke P, et al. Konflik Di Kawasan Pertambangan Timah Bangka Belitung; Persoalan dan Alternatif Solu si. Jakarta: LIPI; 2005.

[19] Zulkarnanin Iskandar, Tri Nuke P, Eko, Tri S.A, et al. Dinamika dan Peran Pertambangan Rakyat di Indonesia. Jakarta: LIPI; 2007. 